\title{
Successful Treatment of Advanced Metastatic Prostate Cancer following Chemotherapy Based on Molecular Profiling
}

\author{
Charles E. Myers $^{\mathrm{a}}$ Gargi Basu $^{\mathrm{b}}$ Brian Wright $^{\mathrm{b}}$ \\ Joanne Mahanes ${ }^{\mathrm{a}}$ Anthony Spinelli ${ }^{\mathrm{c}}$ \\ ${ }^{a}$ Foundation for Cancer Research and Education, Earlysville, Va., ${ }^{b}$ Caris Life \\ Sciences, Phoenix, Ariz., and ${ }^{\mathrm{C}}$ Department of Interventional Radiology, Martha \\ Jefferson Hospital, Charlottesville, Va., USA
}

\section{Key Words}

Prostate $\cdot$ Molecular profiling $\cdot$ Post-chemotherapy response

\begin{abstract}
After Taxotere fails, treatment options for metastatic prostate cancer are limited. The three drugs with FDA approval in this setting, Jevtana, Provenge and Zytiga, are associated with median survivals of less than 2 years. In part, the impact on survival is the result of low response rates, indicating a significant proportion of patients exhibiting de novo resistance to these agents. An alternate approach is to let treatment selection be governed by gene expression profiling so that the treatment is tailored to the specific patient. Here, we report a case of metastatic prostate cancer with a dramatic response to treatment selected based on molecular profiling. This patient had failed LHRH agonist, bicalutamide, Taxotere, and doxorubicin. Molecular profiling showed overexpression of the androgen receptor and he had a dramatic response of measurable disease to second-line hormonal therapy with ketoconazole, estrogen and Leukine.
\end{abstract}

\section{Introduction}

Between 20 and 30,000 men die each year from prostate cancer. For a vast majority of these men, death comes after progression through androgen withdrawal and Taxotere chemotherapy. Before the arrival of Jevtana, Zytiga and Provenge, the median survival after Taxotere was roughly 12 months [1]. These three new drugs each have 
published median survivals of less than 18 months [2-4]. Studies have shown that androgen receptor overexpression is present in many prostate cancers after Taxotere [5]. This was the rationale for the development of Zytiga and now MDV3100. After the use of FDA-approved drugs, there is a fairly long list of drugs where phase II results suggest possible clinical utility and this includes 5-flurouracil, doxorubicin, platinum-based drugs, methotrexate, and etoposide. However, there has been no reliable way to identify which of these drugs might have the greatest chance at success. For most of these drugs, the genes that influence response are known and gene expression profiling offers promise as a means to select agents with the greatest chance of success. In this case report, we present a patient who had failed LHRH agonist, pure antiandrogen, Taxotere and doxorubicin. Molecular profiling showed androgen receptor overexpression and treatment with ketoconazole, estrogen and Leukine was associated with a dramatic response in measurable disease.

\section{Case Report}

This patient was diagnosed with prostate cancer in August of 2000. In September of 2000, he had a radical prostatectomy done at Johns Hopkins. The Gleason grade was $4+3=7$ with vascular invasion. The specimen showed bilateral capsular penetration, but the seminal vesicles and margins were negative. His pathological stage was pT3a N0 Mx. His first post-operative PSA was $0.4 \mathrm{ng} / \mathrm{ml}$ in December of 2000. At that time, his PSA doubling time was approximately 2 weeks. CT scan done in March 2001 showed a $2.8 \times 1.8 \mathrm{~cm}$ left external iliac lymph node. He was given neoadjuvant Zoladex and Casodex followed by external beam radiation between May and July of 2001.

He relapsed by January 2002 with a PSA doubling time of one month. Again, CT scan showed an enlarged left iliac lymph node. By September of 2002, this node had increased to $3.6 \times 2.5 \mathrm{~cm}$. He was then placed on a clinical protocol that combined Taxotere and doxorubicin with hormonal therapy. He had a dramatic PSA response with his PSA dropping from 5 to $0.1 \mathrm{ng} / \mathrm{ml}$. The CT scan showed the lymph node had decreased to $1.3 \times 1.2 \mathrm{~cm}$.

Again, off hormonal therapy, his PSA resumed its one-month doubling time. This was correlated with regrowth of a single lymph node. At this point, the lymph node was surgically removed during the winter of 2005. It was pathologically positive for prostate cancer. At this point, he entered a short remission with an undetectable PSA and negative staging studies until he recurred in July of 2006 with an increasing PSA and a $1.4 \times 1.7 \mathrm{~cm}$ lymph node again in his left pelvis. This time the enlarging node was treated with radiation. This resulted in a PSA that dropped to $0.04 \mathrm{ng} / \mathrm{ml}$. By May of 2008, his PSA again started to increase and a left perirectal node was found at a previously radiated site. At this point, intermittent hormonal therapy was recommended.

By March 2010, he had recurred with a PSA doubling time of 3 months while on hormonal therapy. This was associated with lower abdominal pain and a perirectal mass. A biopsy of the mass showed no PSA expression. In May of 2010, the mass was incompletely removed surgically and showed poorly differentiated carcinoma. He was placed on a clinical trial testing MDV3100, where he was randomized to the placebo arm.

By March of 2011, he had a $2.2 \times 1.7 \times 6.1 \mathrm{~cm}$ mass at the bifurcation of the aorta. In the left hemipelvis, he had a $3.5 \times 2.8 \mathrm{~cm}$ mass. While he had a PSA of only $0.45 \mathrm{ng} / \mathrm{ml}$, CT scan showed a large pelvic mass. His bone scan was negative. The surgical specimen from May 2010 was analyzed with Target Now ${ }^{\mathrm{TM}}$ (Caris Life Sciences, Phoenix, Ariz., USA). Target Now analysis showed androgen receptor overexpression at the protein and RNA level. The staining intensity by immunohistochemistry was $3+$ in $80 \%$ of cells and AR at the mRNA level was overexpressed 2.9 -fold over control tissue as determined by gene expression. Estrogen and progesterone receptor levels were also tested but they were found to be negative. Based on the molecular profiling results in March 11,2011 , he was started on a combination of ketoconazole, estradiol and Leukine. Ketoconazole was initiated at $200 \mathrm{mg}$ every $8 \mathrm{~h}$ and escalated to patient tolerance, which was $600 \mathrm{mg}$ every $8 \mathrm{~h}$. Vivelle dot transdermal estradiol patches $0.1 \mathrm{mg} /$ day were used. These patches are designed to be replaced 
every 3.5 days. We had him place 4 new patches on each day and these were replaced after 3 days. Thus, at any one time, the patient had 12 patches on. This gave a serum estradiol that ranged between $180-360 \mathrm{pg} / \mathrm{ml}$. Leukine was started at $250 \mathrm{mcg}$ per day, but escalated to $500 \mathrm{mcg}$ per day based on patient tolerance. Testosterone levels remained undetectable at less than $15 \mathrm{ng} / \mathrm{dl}$. By August 2011, CT scans showed dramatic resolution of one pelvic mass, partial resolution of the second lesion and a PSA nadir of $0.06 \mathrm{ng} / \mathrm{ml}$ ( fig. 1). Throughout his prostate cancer history, his bone scans have remained negative.

\section{Discussion}

Androgen withdrawal is standard initial treatment for metastatic prostate cancer. However, most men with advanced disease eventually develop castration resistance. Taxotere is the standard initial chemotherapy after failure of androgen withdrawal and is associated with median survivals between 16 and 19 months. Cabazitaxel is the standard second-line chemotherapy agent and it is associated with median survivals of 15 months as compared to just over 12 months for the control group.

Interestingly, in patients who have failed Taxotere, tumor specimens often show overexpression of the androgen receptor. Recent studies demonstrate the so-called 'castration-resistant' tumors are still dependent on androgen receptor signaling. Various molecular mechanisms (e.g., androgen receptor gene amplification, overexpression, or mutations, enhanced AR signal transduction) have been reported in castration-resistant prostate cancers [6]. These molecular mechanisms allow the androgen receptor to be activated at castrate levels of testosterone. This has been confirmed in a series of laboratory experiments where prostate cancer cell lines have been developed that grow well at $1 / 100$ to $1 / 1,000$ the normal testosterone concentration. Overexpression of the androgen receptor is one of the more common mechanisms involved in this adaptation to low androgen levels. Androgen receptor tyrosine phosphorylation has also been shown to facilitate androgen receptor function at low testosterone levels. These findings have led to a search for better means of reducing serum testosterone levels or blocking the androgen receptor.

Abiraterone, a $17 \alpha$-hydroxylase/C17,20 lyase (CYP17A1) receptor antagonist, is the first drug approved to address this problem. Abiraterone is very effective at inhibiting synthesis of testosterone as serum levels of this hormone become undetectable. This drug was FDA-approved for post-Taxotere patients based on a survival extension of 3.9 months.

At the time this patient started second-line treatment in March 2011, the FDA had not yet approved abiraterone. For this reason, we chose to use ketoconazole, an older drug reported to decrease androgen synthesis. In addition to inhibiting $17 \alpha$-hydroxylase/C17,20 lyase, ketoconazole also inhibits a wide range of other microsomal enzymes and hence, lacks the specificity of abiraterone. This lack of specificity on the part of ketoconazole makes it a much difficult drug to use clinically unlike abiraterone [2].

We elected to add Leukine to the treatment program based on reports of synergy between ketoconazole and Leukine. Investigators at University of California San Francisco reported a $75 \%$ response to this combination in patients who had failed androgen withdrawal [7]. Finally, we added transdermal estradiol because estradiol is 
also reported to decrease serum testosterone. This strategy proved successful and serum testosterone levels have remained undetectable during treatment [8].

\section{Conclusions}

In summary, this patient had failed extensive treatment with hormonal therapy as well as treatment with Taxotere/doxorubicin. While he was clinically hormone refractory, his cancer overexpressed androgen receptor and he has had radiologic response of his cancer after 5 months on second-line hormonal therapy. Molecular profiling was successful in predicting response to second-line hormonal therapy in this heavily pretreated patient.

\section{Disclosure Statement}

Caris Life Sciences employs Gargi Basu and Brian Wright. Charles E. Myers is funded to participate in a clinical trial funded by Caris Life Sciences to evaluate the role of molecular profiling in the management of advanced prostate cancer patients.

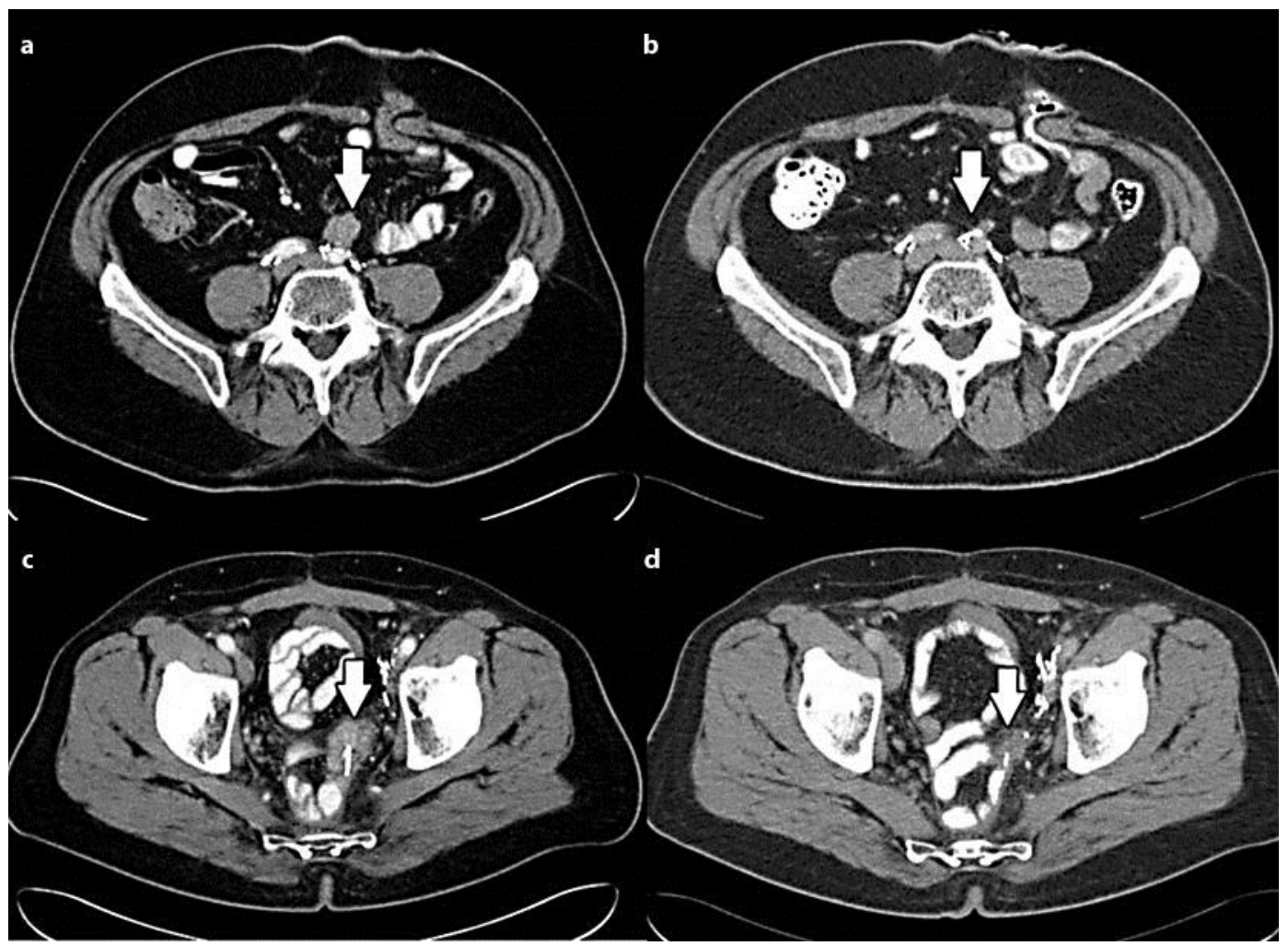

Fig. 1. The patient had two metastatic lesions at the start of treatment. In each image, the metastatic lesion location is indicated by the white arrow. $\mathbf{a}$ and $\mathbf{b}$ show one metastasis before and after treatment, respectively. $\mathbf{c}$ and $\mathbf{d}$ show the second lesion before and after treatment, respectively. 


\section{References}

1 Tannock IF, de Wit R, Berry WR, Horti J, Pluzanska A, Chi KN, Oudard S, Theodore C, James ND, Turesson I, Rosenthal MA, Eisenberger MA: Docetaxel plus prednisone or mitoxantrone plus prednisone for advanced prostate cancer. N Engl J Med 2004;351:1502-1512.

2 de Bono JS, Logothetis CJ, Molina A, Fizazi K, North S, Chu L, Chi KN, Jones RJ, Goodman OB Jr, Saad F, Staffurth JN, Mainwaring P, Harland S, Flaig TW, Hutson TE, Cheng T, Patterson H, Hainsworth JD, Ryan CJ, Sternberg CN, Ellard SL, Flechon A, Saleh M, Scholz M, Efstathiou E, Zivi A, Bianchini D, Loriot Y, Chieffo N, Kheoh T, Haqq CM, Scher HI; COU-AA-301 Investigators: Abiraterone and increased survival in metastatic prostate cancer. N Engl J Med 2011;364:1995-2005.

-3 de Bono JS, Oudard S, Ozguroglu M, Hansen S, Machiels JP, Kocak I, Gravis G, Bodrogi I, Mackenzie MJ, Shen L, Roessner M, Gupta S, Sartor A0: Prednisone plus cabazitaxel or mitoxantrone for metastatic castration-resistant prostate cancer progressing after docetaxel treatment: a randomised open-label trial. Lancet 2010;376:1147-1154

-4 Kantoff PW, Higano CS, Shore ND, Berger ER, Small EJ, Penson DF, Redfern CH, Ferrari AC, Dreicer R, Sims RB, Xu Y, Frohlich MW, Schellhammer PF: Sipuleucel-T immunotherapy for castration-resistant prostate cancer. N Engl J Med 2010;363:411-422.

5 Culig Z, Bartsch G: Androgen axis in prostate cancer. J Cell Biochem 2006;99:373-381.

6 Ryan CJ, Tindall DJ: Androgen receptor rediscovered: the new biology and targeting the androgen receptor therapeutically. J Clin Oncol 2011;29:3651-3658.

-7 Ryan CJ, Weinberg V, Rosenberg J, Fong L, Lin A, Kim J, Small EJ: Phase II study of ketoconazole plus granulocyte-macrophage colony-stimulating factor for prostate cancer: effect of extent of disease on outcome. J Urol 2007;178:2372-2376, discussion 2377.

-8 Langley RE, Godsland IF, Kynaston H, Clarke NW, Rosen SD, Morgan RC, Pollock P, Kockelbergh R, Lalani el N, Dearnaley D, Parmar M, Abel PD: Early hormonal data from a multicentre phase II trial using transdermal oestrogen patches as first-line hormonal therapy in patients with locally advanced or metastatic prostate cancer. BJU Int 2008;102:442-445. 